\title{
GUIDE TO THE ENTRIES
}

glossaries of such terms and titles, together with brief descriptions of the conditions for the award of the corresponding degrees and diplomas.

Entries with tables which indicate the composition of academic staffs show this in descending order of rank, and the respective titles are given in the language of the country concerned. In a few cases, however, institutions have themselves employed English or French terminology, and this has been retained. It will be noted that some have used a more restrictive definition of academic staff in compiling these tables than in indicating the size of the staff of their different faculties, departments and schools. The figures given under the latter headings (and also in the entries where no table is given) are for full-time staff, with those for part-time staff in parenthesis.

A page reference to each institution will be found in the index under its official title and, where relevant, also under the English translation provided for it.

Membership of the International Association of Universities is indicated by an asterisk, e.g.

\section{*Universita degli Studi di Bologna}

A full list of members will be found on pages 1121 to 1129 .

\section{ABBREVIATIONS}

As the Handbook is intended for international use, abbreviations have been employed as little as possible. Those which do occur are generally well known and should not give rise to difficulties. They are:

$\begin{array}{lllll}\text { A. } & - & - & - & \text { Academy } \\ \text { C. } & - & - & - & \text { College } \\ \text { Ce. } & - & - & - & \text { Centre } \\ \text { D. } & - & - & - & \text { Department-Division } \\ \text { F. } & - & - & - & \text { Faculty } \\ \text { I. } & - & - & - & \text { Institute } \\ \text { L. } & - & - & - & \text { Laboratory } \\ \text { P. } & - & - & - & \text { Programme } \\ \text { S. } & - & - & - & \text { School } \\ \text { Sec. } & - & - & - & \text { Section } \\ \text { Sem. } & - & - & - & \text { Seminar } \\ \text { U. } & - & - & - & \text { University } \\ \text { Ut. } & - & - & - & \text { Unit } \\ \text { c. } & - & - & - & \text { circa } \\ \text { sem } & - & - & - & \text { semesters } \\ \text { vols } & - & - & - & \text { volumes } \\ \text { yr(s) } & - & - & - & \text { year (s) } \\ & \text { Degree and } & \text { Diploma } & \text { Abbreviations }\end{array}$

Apart from the almost universal use of the style Dr., the use of letters or contractions to signify particular academic or professional qualifications is customary in some countries but not in others. Abbreviations of this nature are listed, where relevant, in the information given about the degrees and diplomas awarded by the different institutions. 
